
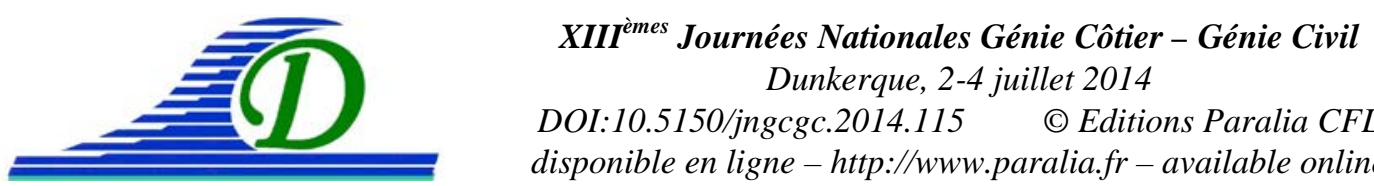

DOI:10.5150/jngcgc.2014.115 @ Editions Paralia CFL disponible en ligne - http://www.paralia.fr - available online

\title{
Reuse silt given from dredging dam in order to protect the environment
}

\author{
Abdélaziz SEMCHA ${ }^{1}$, Fatiha KAZI-AOUAL ${ }^{1}$, Belkacem MEKERTA ${ }^{1}$, \\ Mohammed AMEUR ${ }^{1}$
}

\author{
1. Ecole Nationale Polytechnique d'Oran (ENPOran), LABMAT, \\ Route d’Es Sénia, B.P. 1523, Oran El M’Naouer, 31000, Algérie. \\ asemcha@yahoo.fr
}

\begin{abstract}
:
In semi-arid weather countries, the public works as dams are silted in a short time. Our study contributes to make the life work of a dam longer. Our idea is to develop a process using the material extracted by dredging, as first matter to product hydraulic cement. The various physical, chemical and mineralogical analyses carried out on the silt samples showed mineralogical structures allowing several routes of development. We are interested in the very fine solid particles carried by erosion and deposited downstream of the dam. This material has caused many environmental problems after it's extracted of. In fact, the crystalline structure of the amorphous clay fraction of this silt reacts with water in the presence of lime, as hydraulic cement.

Experimentally, silt samples were calcimined at a temperature less than $800{ }^{\circ} \mathrm{C}$, and an amorphous structure appeared. The desired pozzolanic character was therefore confirmed.
\end{abstract}

Key words: Dredging, Silt, Calcinations, Amorphous, Cement, Pozzolana, Lime.

\section{Introduction}

A large number of Algerian dams are severely silted up. The Bouhanifia dam, in this moment, is dredged in order to extract six millions of cubic meters among forty millions of silt containing in the basin of the dam. The question is how to do with this material when it is imperative that solid silt deposits are cleared out?

Using the material dredged out as a source of raw material is a genuine route for investigation. Mineralogical analysis using X-ray diffractometry to complete the dimensional analysis and determine the physical characteristics of the silt from dredging the dam showed a mineralogical composition comparable to that of hydraulic binder, but with a low proportion of lime. The behaviour of the intact silt was comparable to that of clay: it softens again in water.

Thermal activation by calcination of the silt at an average temperature of $750{ }^{\circ} \mathrm{C}$ produced an unstable mineralogical structure that reacted to water in the presence of lime and shows a new strong comportment. Amorphous combinations appeared parallel to $\mathrm{CaO}$, as well as new crystalline complexes. 


\section{Reminders and definitions}

2.1 Hydraulic binder and pozzolana (general information), (AMBROISE, 1984)

Hydraulic binder is a mineral powder that forms a paste when mixed with water and forms stable hydrated compounds that are almost insoluble in water. They adhere to each other and to neighbouring ballast and create strong cement for mortar and concrete. Pozzolananic property is defined as the ability of a product to form stable hydrated compounds at ordinary temperatures, in the presence of water and in combination with lime. In other words, pozzolana's mineralogical composition is similar to cement but comparatively low in lime. With the addition of a sufficient quantity of lime the pozzolanic compound acquires the properties of a hydraulic binder.

\subsection{Hydration of hydraulic cement (releasing free lime)}

During hydration Portland cement (CEM I) frees between 20\% and 25\% of its weight in hydrated lime $\mathrm{Ca}(\mathrm{OH})_{2}$ in 28 days. This lime comes from anhydrous CEM I silicates which are unstable in the presence of water. This lime can lead to specific alterations in concrete and mortar.

\subsection{Lime-pozzolana reaction (fixing the lime), (MESSI, 1988)}

The particular property of a mixture of pozzolana, lime and water is to harden and form a binder. Pozzolanic activity is the definition given to the phenomenon that at normal temperatures transforms these mixtures into hard and compact materials within the same time as ordinary cement.

These reactions can be written as the following formulae:

Silica + lime + water $\rightarrow$ hydrated calcium silicate

Alumina + lime + water $\rightarrow$ hydrated calcium aluminate

The main phases produced by the pozzolana-lime reaction are:

CHS (hydrated calcium silicate) in the form of low crystalline salt of variable composition.

$\mathrm{C}_{4} \mathrm{AH}_{13}$ (hydrated calcium aluminate).

And in certain conditions it is possible to find hydrated gehlenite $\left(\mathrm{C}_{2} \mathrm{ASH}_{8}\right)$, ettringite or monosulfoaluminate.

This pozzolanic reaction can only be seen in materials comprising mineral phases in which the silica and alumina are partially available. The pozzolanic activity of amorphous calcinated clay and volcanic ash, which is essentially vitreous, is due to this peculiarity. 


\section{XIII ${ }^{\text {èmes }}$ Journées Nationales Génie Côtier - Génie Civil \\ Dunkerque, 2-4 juillet 2014}

\section{Analysis made on the dam silt}

\subsection{Granular analysis}

The next granular curve shows that $88 \%$ of the studied mud is as lemon and clay. This situation make easy to select the fine particles of the mud for testing.

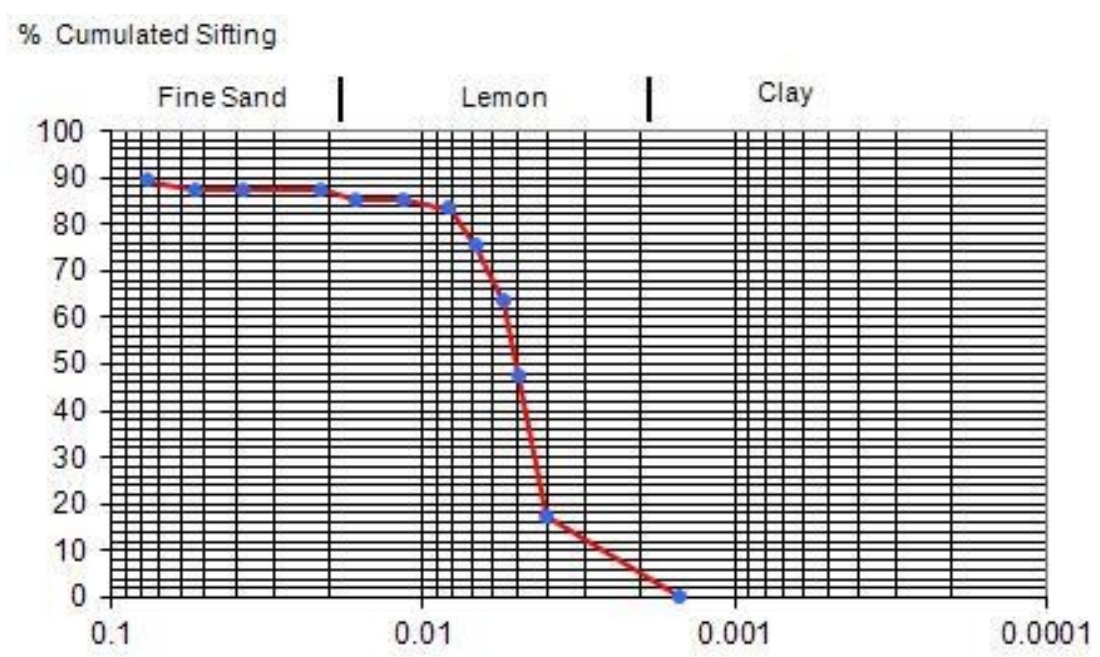

Figure 1. Granular curve of BouHanifia's mud.

\subsection{Mineralogical analysis of the dam silt}

Petrographic analysis made on selected samples given from BouHanifia's dam shows the results presented in table 1.

Carbonate content:

- 26\% calcite,

- 4\%-6\% dolomite.

Global chemical analysis produced the results on average content for the samples analysed (table 2).

If we consider that all the alumina is in the form of kaolinite we will have:

- 23.17\% kaolinite $\left(\mathrm{Al}_{2} \mathrm{O}_{3} 2 \mathrm{SiO}_{2}\right)$,

- $5.15 \%$ silica bound to kaolinite,

- 35\% free silica.

Table 1. Petrographic analysis results.

\begin{tabular}{lll}
\hline Constituents & Fraction $\mathbf{0 . 0 6 3} \mathbf{~ m m}$ & Fraction $\mathbf{0 . 0 0 2} \mathbf{~ m m}$ \\
\hline $\begin{array}{l}\text { Main Constituents } \\
(>25 \%)\end{array}$ & Quartz & Quartz, Calcite, Dolomite, Kaolinite \\
\hline $\begin{array}{l}\text { Seconder Constituents } \\
(10-25 \%)\end{array}$ & Calcite, Kaolinite & $\begin{array}{l}\text { Kaolinite, Illite, Chlorite, Dolomite, } \\
\text { Calcite }\end{array}$ \\
\hline Accessory Constituents & Illite, Chlorite, & Made up of a base of micas and clay \\
$(<10 \%)$ & Dolomite, Kaolinite & minerals (feldspath), Chlorite \\
\hline
\end{tabular}


Thème 8 - Gestion et valorisation des sédiments marins

Table 2. Chemical analysis results.

\begin{tabular}{lllllllll}
\hline $\mathrm{Na} 2 \mathrm{O}$ & $\mathrm{MgO}$ & $\mathrm{Al} 2 \mathrm{O} 3$ & $\mathrm{SiO} 2$ & $\mathrm{P} 2 \mathrm{O} 5$ & $\mathrm{~K} 2 \mathrm{O}$ & $\mathrm{CaO}$ & $\mathrm{MnO}$ & $\mathrm{Fe} 2 \mathrm{O} 3$ \\
\hline $0,9 \%$ & $5,80 \%$ & $13-15 \%$ & $53 \%$ & $0,21 \%$ & $2,5 \%$ & $1 \%$ & $0,10 \%$ & $6 \%$ \\
\hline
\end{tabular}

\section{Activation by calcinations}

\subsection{Pozzolanic activity}

The pozzolanic activity includes all the physical and chemical reactions produced when water comes into contact with lime, silica or alumina. These reactions pass through a preliminary solution, as it is accepted that the transfer of matter takes place in a dissolved state (PERA, 1988). In fact dissolution involves ionization followed by diffusion of the ions in the aqueous phase, where the hydrates are going to form and develop.

The "reactivity" of the aqueous phase will be defined in these conditions as being the "quantity of material that is made into solution calculated per surface unit and time unit".

The least stable clay structures are the most soluble, therefore the most reactive. This metastable crystalline structure is acquired by calcination.

\subsection{Calcination of the clay (MURAT, 1982)}

If the clay is subjected to moderate heating, it hardens, loses its free water and gradually contracts. Furthermore if the temperature remains below $200{ }^{\circ} \mathrm{C}$ this phenomenon becomes reversible.

At temperatures greater than $200{ }^{\circ} \mathrm{C}$, the clay loses its water constituent in proportion to the rise with temperature rise and is broken down into silica and alumina:

$2 \mathrm{SiO}_{2} \cdot \mathrm{Al}_{2} \mathrm{O}_{3} \cdot 2 \mathrm{H}_{2} \mathrm{O} \rightarrow 2 \mathrm{SiO}_{2} \cdot \mathrm{Al}_{2} \mathrm{O}_{3}+4 \mathrm{H}_{2} \mathrm{O}$

Kaolin $\rightarrow$ metakaolin + water

If the temperature remains lower than a given threshold $\left(800^{\circ} \mathrm{C}\right)$ only the dehydration of the kaolin takes place, producing metakaolin and water.

At about $850{ }^{\circ} \mathrm{C}$ the following reactions will be noticed:

$3\left(2 \mathrm{SiO}_{2} \cdot \mathrm{Al}_{2} \mathrm{O}_{3}\right) \rightarrow 2 \mathrm{SiO}_{2} \cdot 3 \mathrm{Al}_{2} \mathrm{O}_{3}+2 \mathrm{SiO}_{2}$

metakaolin $\rightarrow$ mullite $\quad+$ tridinite

The prolonged thermal treatment initiates a slow recrystallisation of the metakaolin and leads to stable structures, which is not the aim and should be avoided. On stopping the calcination before the start of this recrystallisation (before the temperature reaches $800^{\circ} \mathrm{C}$ ), the clay structures remain in an amorphous and unstable state. It is this instability that gives the desired pozzolanic character: "it reacts with the free lime present to form calcium silicates and aluminates" (SEMCHA \& MEKERTA, 2002). 


\section{XIII ${ }^{\text {èmes }}$ Journées Nationales Génie Côtier - Génie Civil \\ Dunkerque, 2-4 juillet 2014}

It is essential that the calcination process is halted before recrystallisation begins, in order to attain an unstable and therefore reactive product. The firing temperature was fixed experimentally at $750{ }^{\circ} \mathrm{C}$, and this was maintained constantly for five hours.

\subsection{Production of pozzolanic cement from the fired silt (SEMCHA, 2006)}

The concept of substituting a certain amount of pozzolanic fired silt in Portland cement which hydration frees the lime (Candlot salt) allows binders to be obtained with similar or even better characteristics than those of Portland cement alone. In fact the free lime is fixed by the added artificial pozzolana.

On the face of it, the hydration of CEM I frees $20 \%$ to $25 \%$ of its weight in lime and the substitution of pozzolana or fired silt is envisaged in the same proportion.

\subsubsection{Preparation and firing of the silt}

The silt was sampled from the disposal site at the mouth of the Bouhanifia dam, dried in an oven at $50{ }^{\circ} \mathrm{C}$, crushed and sifted by means of a dry process. The grains that passed through 250 micrometers and which represented more than $95 \%$ of the sample were recovered for firing.

Firing process (calcination) was carried out in small quantities, because of the size of the ovens available. The firing operation needed certain precautions: to avoid thermal shock, the speed of firing was controlled at $5{ }^{\circ} \mathrm{C}$ a minute, the firing temperature of $750{ }^{\circ} \mathrm{C}$ was maintained for 5 hours and the silt was kept protected from air and humidity after calcination.

\subsubsection{Mixtures studied}

To determine the reactivity of our product we opted for the production of three mixtures of cement and calcinated silt, with one sample of cement on its own. Table 3 shows the samples composition.

Table 3. Composition of the studied samples.

\begin{tabular}{lllll}
\hline $\boldsymbol{N}^{\circ}$ of Sample & $\mathbf{1}$ & $\mathbf{2}$ & $\mathbf{3}$ & $\mathbf{4}$ \\
\hline$\%$ of Cement & 70 & 50 & 30 & 100 \\
\hline$\%$ of Calcined silt & 30 & 50 & 70 & 00 \\
\hline
\end{tabular}

\section{Experimental study}

\subsection{Production of samples}

Trials of mechanical resistance can be made on concrete, mortar or pastes made from hardened binder. Concrete and mortar call for granular methods of composition where errors due to inaccuracies will be added to those due to binding pastes. Furthermore, 


\section{Thème 8 - Gestion et valorisation des sédiments marins}

calcination of the silt in low capacity ovens limited our production of artificial pozzolana. For all these reasons, we carried out the experimental part purely on samples of binder pastes and for optimization of mixing water only, we used $4 \times 4 \times 16$ samples of normal mortar. For the various mixtures we took cylindrical micro-samples of $20 \mathrm{~mm}$ in diameter and $40 \mathrm{~mm}$ in height. The mechanical resistance at breaking point was then measured under single axis compression made on the micro-samples.

\subsection{Mechanical trials}

Knowing that performance due to pozzolanic properties is progressively acquired over time, compression break point trials were carried out at the following intervals: 7 days, 15 days, 28 days, 60 days, 90 days and 120 days. The resistance value given for breaking point is the average value taken from ten experimental values for each mixture. A consistency test was used to determine the quantity of mixing water for each mixture. In a second stage the mixing water quantity was optimized based on each value obtained during the consistency test with the aid of the production of $4 \times 4 \times 16$ samples of the normal mortar tested under compression at 7 days. The water/binder ratio retained was that which corresponded to the maximum resistance (Figure 2).

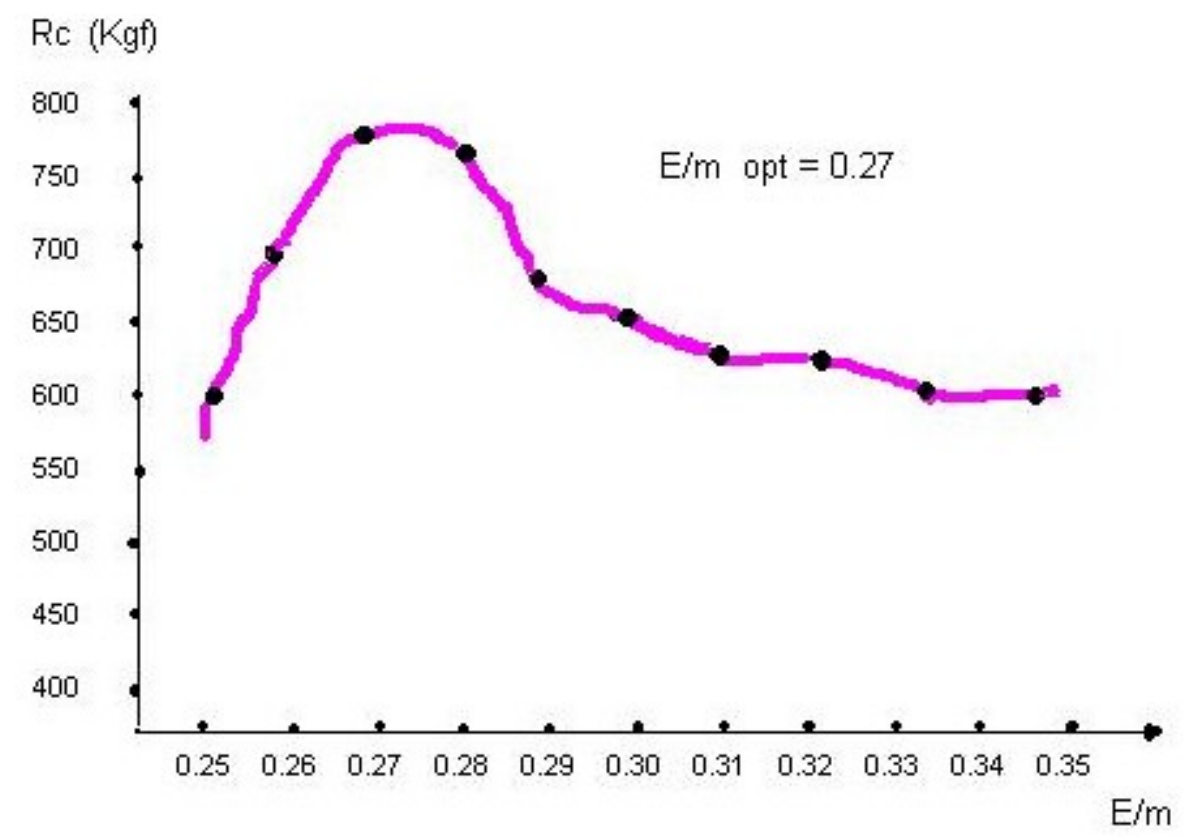

Figure 2. Optimisation of mixing water.

The samples were kept at $100 \%$ humidity until the trial date on each occasion. They were dried at $50{ }^{\circ} \mathrm{C}$ in an unventilated oven for 24 hours. The compression trials were carried out using a press equipped with captor-forces noting the breaking point force. The results are compared in figure 3 and presented in figure 4. 


\section{XIII ${ }^{\text {èmes }}$ Journées Nationales Génie Côtier - Génie Civil \\ Dunkerque, 2-4 juillet 2014}

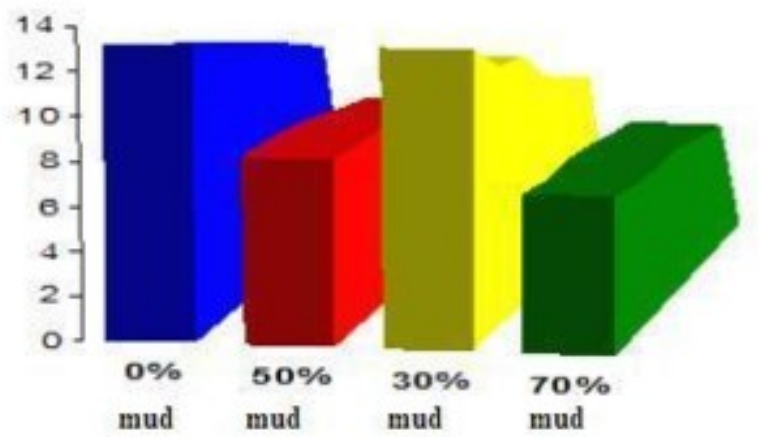

Figure 3.Comparative results of the various\% of substituted calcinated silt.

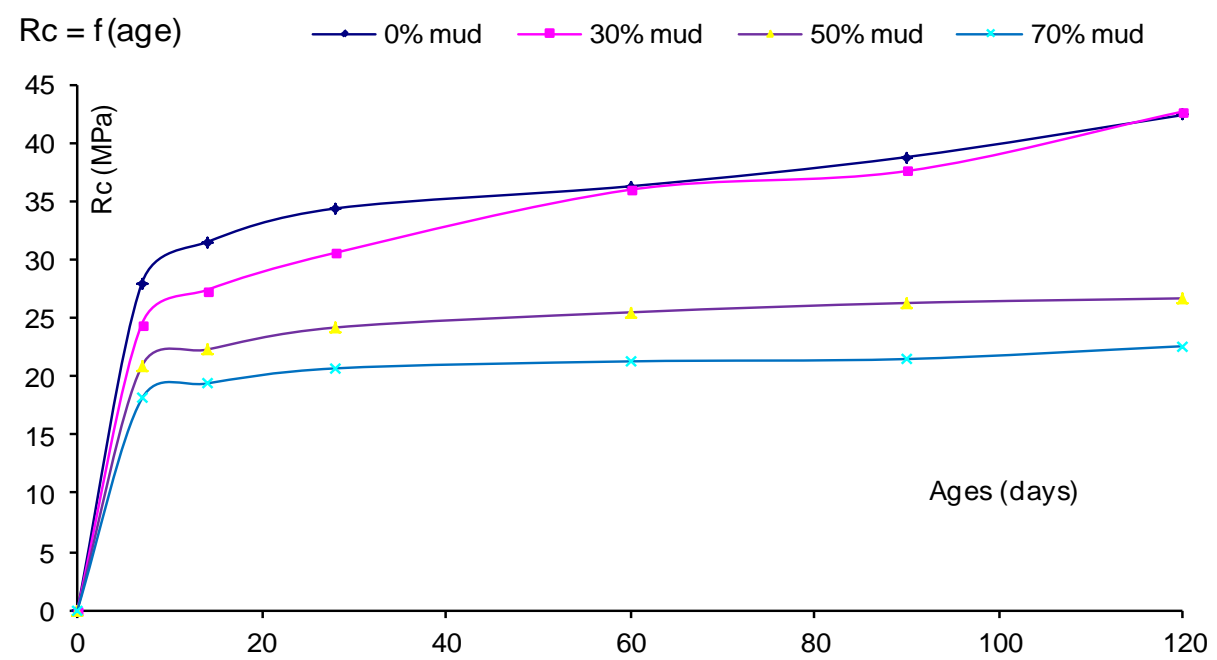

Figure 4. Mechanical resistance of the various\% of substituted calcinated silt.

\subsection{Results and comments}

Figure 2 represents the optimal value obtained for the control sample ( $0 \%$ added). Optimum water/mixture is 0.27 . The same process was carried out for the other mixtures. A linear tendency is shown in the variation of the water/mixture values depending on the percentage added.

Figure 3 and figure 4 shows that among the mixtures studied, 30\% calcinated silt gave resistance values comparable to those of the control. In the long term ( 90 days) it was $30 \%$ mixture of calcinated silt that reached resistance value of the cement on its own, which confirms the pozzolanic reactivity acquired by the calcinated silt. This resistance is only observed in the long term, as the pozzolanic reaction can only take place after the hydration of the CEMI and the release of the lime. 


\section{Conclusion and prospects}

The pozzolanic effect of the calcinated silt was thus confirmed by the mechanical comportment of the mixtures containing the calcinated silt.

The 30\% mixture of calcinated silt and 70\% cement is doubly interesting: not only was the same resistance as that of the cement on its own achieved solely by storing it for longer time, but also the pozzolanic effect of the calcinated silt was confirmed.

This study has been carried out on samples of mixed plaster binder. Similar studies can be done on mortar and concrete in order to confirm the pozzolana properties on a composite material.

The study of the durability of these products under harsh conditions should be permitted in order to characterize the domains of use for this composite based on cement and calcinated silt.

Using silt given from dredging dam in any technologic process contribute to extend the life of the dam and to protect the environment furthermore we shouldn't look at it as waste but as first matter.

In order to select a butt for using the fired silt, it is necessary to carry on the technologic process an economic evaluation.

\section{Références bibliographiques}

MURAT M. (1982). Activation thermique des argiles en réaction solaire, étude des ciments métakaolins (Thermic activation of clay, solar reaction, study of metakaolin cements). Final research report PIRDES-CNRS, Paris.

AMBROISE J. (1984). Elaboration des liants pouzzolaniques à moyenne température et étude de leurs propriétés physicochimiques (Development of pozzolanic binders at normal temperatures and study of their physic-chemical properties). Thesis, INSA Lyon, France.

MESSI A. (1988). Propriétés des ciments pouzzolaniques élaborés à partir de latérites activées thermiquement (Properties of pozzolanic cements developed from thermically activated laterites). Thesis, INSA Lyon, France.

PERA J. (1988). Liants pouzzolaniques de synthèse (Synthesising pozzolanic binders), Interministerial programme, Laboratoire des matériaux minéraux (Mineral Laboratory). INSA Lyon, France.

SEMCHA A. (2006). Valorisation des sédiments de dragage : Applications dans le BTP, cas du barrage de Fergoug. PhD Thesis of Université de Reims Champagne Ardenne (URCA), France.

SEMCHA A., MEKERTA B. (2002). Valorisation des matériaux locaux en vue de leur utilisation dans les constructions en génie civil (Evaluation of local materials with a view to their use in civil engineering constructions). Research report ANDRU, Algeria. 